\title{
SAUDAÇÃO AO DR. ALUISIO MENDES, POR OCASIÃO DA CERIMÔNIA DE SUA POSSE NA ACADEMIA BRASILEIRA DE LETRAS JURÍDICAS
}

Sergio de Andréa Ferreira

Professor titular de Direito Administrativo na UERJ, na Universidade Santa Úrsula e na Fundação Getúlio Vargas (Aposentado). Desembargador Federal do TRF 2a Região (Aposentado). Membro da Academia Brasileira de Letras Jurídicas.

Já me encontrava prestes a aposentar-me do cargo de Professor de Direito Administrativo da UERJ, quando o exercício da carreira docente propiciou-me um especial privilégio: o de ter, como aluno, o agora Confrade, Aluísio Mendes.

A experiência de 30 anos de magistério permitiu-me, desde logo, vislumbrar-lhe um brilhante futuro no campo jurídico.

Atento às exposições, invariavelmente procurava-me, após a aula, para conversar sobre a matéria lecionada. E, trocando ideias - porquanto ele as tinha para trocar -, descíamos os sete andares de rampa, que nos levavam até a saída do Campus.

O interesse pelo estudo, a argúcia de raciocínio, a cultura, impressionavamme sobremodo.

O passar do tempo somente veio a confirmar a previsão; e, somando títulos, êxitos em concursos públicos, produção doutrinária, Aluisio se fez um jovem jurisconsulto, um scholar, de fama internacional, o que lhe é facilitado pelo domínio de várias línguas estrangeiras: o inglês, o alemão, o francês, o espanhol, o italiano. 
Ao ingressar no Curso de Direito, já era graduado em Comunicação Social, o que desenvolvera seu talento, inato, de interação; sua capacidade docente, sua competência para presidir comissões, coordenar grupos de trabalho e obras coletivas.

Sua copiosa e rica bibliografia, especialmente no campo do Direito Processual, o tornou um dos grandes doutrinadores desse ramo jurídico, no qual tem pontificado, em vários segmentos, como no dos meios de solução coletiva de conflitos, no das demandas repetitivas, no da mediação e conciliação, no dos juizados especiais.

Sintonizado, portanto, com a atualidade do Direito, seu espírito jovem, aliado a um expressivo tirocínio e aprofundado saber, versa ele sobre os diferentes temas da processualística, com rara habilidade e criatividade; sempre voltado para a efetividade do Direito, na prossecução de seu superior objetivo, a realização da Justiça e acesso à mesma.

Seu currículo funcional engloba o exercício do magistério, a participação em numerosos congressos, o desempenho das atribuições do Ministério Público e, posteriormente, da Magistratura, na qual se destaca por sua atuação, por seus brilhantes votos, como Desembargador Federal; sendo Presidente da $5^{\text {a }}$ Turma Especializada do TRF $-2^{\mathrm{a}}$ Região.

Ao privilégio acadêmico universitário, por ter sido seu professor, soma-se, já agora, a honra, também acadêmica, de saudá-lo no pórtico de sua trilha como Membro Titular da ABLJ, a qual o recebe com os mais efusivos encômios; e a que Aluisio enobrecerá com seu entusiasmo laborativo, com o brilho de sua inteligência e com a contribuição, que, neste foro, continuará dando ao Direito Brasileiro; já que este sodalício tem por finalidade aliar o estudo do Direito ao aperfeiçoamento das letras jurídicas.

O presente momento conjuga, para mim, a honraria de saudar o novo Companheiro com uma emoção muito particular. Aluisio foi empossado na Cadeira antes 
Revista Eletrônica de Direito Processual - REDP.

Rio de Janeiro. Ano 13. Volume 20. Número 2. Maio a Agosto de 2019

Periódico Quadrimestral da Pós-Graduação Stricto Sensu em Direito Processual da UERJ

Patrono: José Carlos Barbosa Moreira (in mem.). ISSN 1982-7636. pp. 385-388

www.redp.uerj.br

ocupada pelo grande advogado, Brenno de Andrade, atuante no Fórum, e nos órgãos representativos da advocacia; e presente em sessões desta Academia, da qual é um dos cofundadores, até os seus 105 anos de idade. O patrono da Cadeira é seu pai, o Professor Odilon de Andrade, Catedrático, exatamente, de Direito Processual Civil, na Faculdade do Catete, e com quem tive proveitosas aulas.

Ademais, sou amigo da família de Brenno. Aqui presentes estão: os filhos, Vera Lúcia e Brenno Filho, e sua esposa Isabel; os últimos, colegas de Serviço Jurídico da Light; o sobrinho, Desembargador André Gustavo Corrêa de Andrade; e a Desembargadora Teresa de Andrade Castro Neves, sobrinha-neta.

Outrossim, sucedi ao irmão de Brenno, Luiz Antonio de Andrade, outro famoso causídico, doutrinador e Desembargador, na Cadeira que tem, como patrono, Luiz Machado Guimarães, ícone da moderna processualística civil em nosso País.

Nossas Cadeiras, portanto, se irmanam, o que vem ao encontro da afinidade que me une a Aluisio.

É invejável sua extraordinária capacidade de trabalho; a facilidade com que soluciona questões, sua destreza intelectual, virtudes que lhe permitem trabalhar em várias frentes, no Brasil e no Exterior.

Ainda mais: beneficia-se de um sadio ambiente familiar, em que sua esposa, Marjorie, seus filhos, Carolina e Christian, lhe propiciam os insumos afetivos, indispensáveis, do amor, do carinho, da admiração.

Sentimento, este último, que também lhe devotam seus amigos, colegas e alunos.

Está certa a ABLJ que o novel Acadêmico, com sua juventude, entusiasmo, conhecimento, dedicação ao estudo, ao labor, dará, neste espaço de ciência, inestimável 
Revista Eletrônica de Direito Processual - REDP.

Rio de Janeiro. Ano 13. Volume 20. Número 2. Maio a Agosto de 2019

Periódico Quadrimestral da Pós-Graduação Stricto Sensu em Direito Processual da UERJ

Patrono: José Carlos Barbosa Moreira (in mem.). ISSN 1982-7636. pp. 385-388

www.redp.uerj.br

contribuição ao progresso do pensamento e das letras jurídicas, enriquecendo-os de modo significativo.

Assim, querido amigo, nesta fulgente solenidade, enriquecida com tão seleta audiência, celebração da amizade e do prestígio que desfruta, você, ao atravessar os umbrais desta corporação, inicia uma fértil caminhada, em cujo percurso nos brindará com novas joias de seu saber.

Parabéns, Aluisio! Parabéns, Academia Brasileira de Letras Jurídicas! 